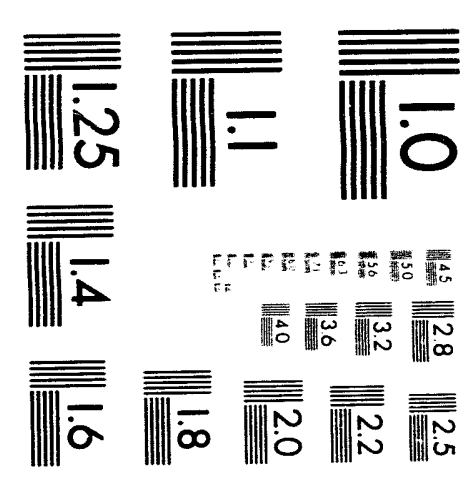



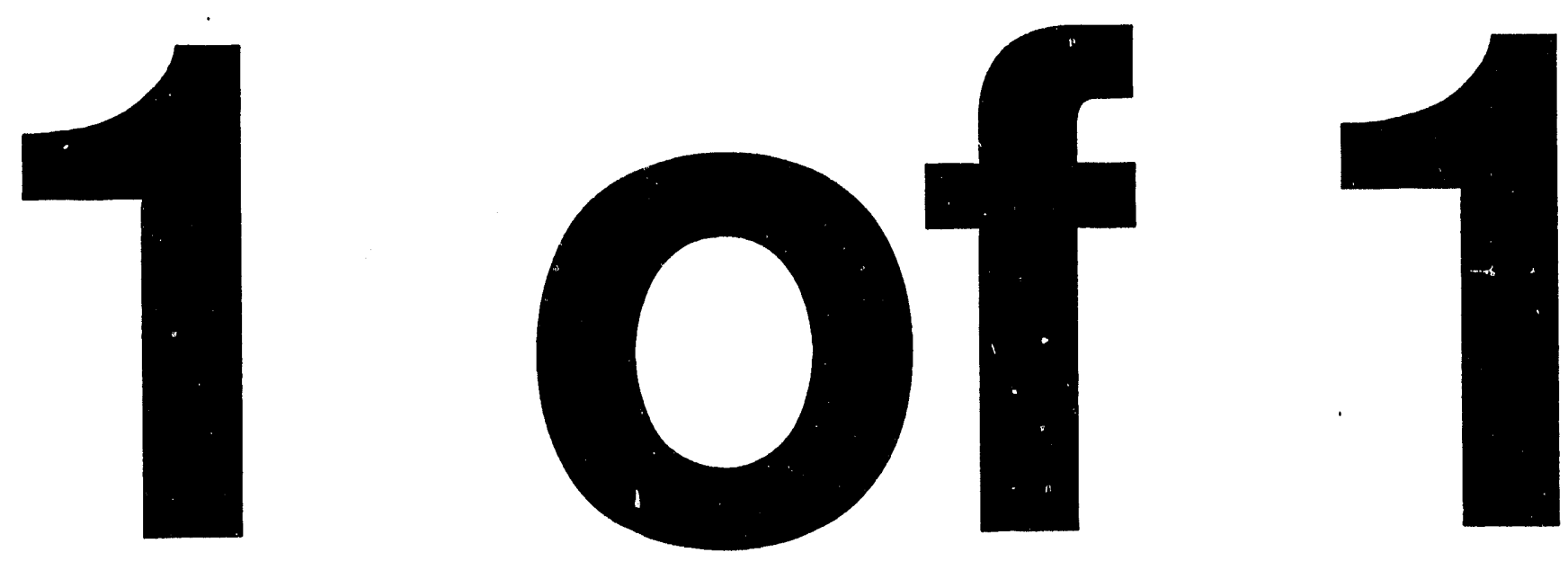


\title{
THE SUMMARY OF NATIONAL ENVIRONMENTAL RESTORATION NEEDS
}

April 30, 1993

\section{DISCLAIMER}

\begin{abstract}
This report was prepared as an account of work sponsored by an agency of the United States Government. Neither the United States Government nor any agency thereof, nor any of their employees, makes any warranty, express or implied, or assumes any legal liability or responsibility for the accuracy, completeness, or usefulness of any information, apparatus, product, or process disclosed, or represents that its use would not infringe privately owned rights. Reference herein to any specific commercial product, process, or service by trade name, trademark, manufacturer, or otherwise does not necessarily constitute or imply its endorsement, recommendation, or favoring by the United States Government or any agency thereof. The views and opinions of authors expressed herein do not necessarily state or reflect those of the United States Government or any agency thereof.
\end{abstract}

\section{Westinghouse Savannah River Company \\ Savannah River Site \\ Aiken, South Carolina 29808}

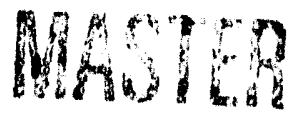




\section{DISCLAIMER}

This report was prepared as an account of work sponsored by an agency of the United States Government. Neither the United States Government nor any agency thereof, nor any of their employees, makes any warranty, express or implied, or assumes any legal liability or responsibility for the accuracy, completeness, or usefulness of any information, apparatus, product, or process disclosed, or represents that its use would not infringe privately owned rights. Reference herein to any specific commercial product, process, or service by trade name, trademark, manufacturer, or otherwise does not necessarily constitute or imply its endorsement, recommendation, or favoring by the United States Government or any agency thereof. The views and opinions of authors expressed herein do not necessarily state or reflect those of the United States Government or any agency thereof.

This report has been reproduced directly from the best available copy.

Available to DOE and DOE contr. sturs from the Office of Scientific and Technical Information, P. O. Box 62, Oak Ridge, TN 37831; prices available from (615) $576-8401$.

Available to the public from the National Technical Information Service, U. S. Department of Commerce, 5285 Port Royal Rd., Springfield, VA 22161 


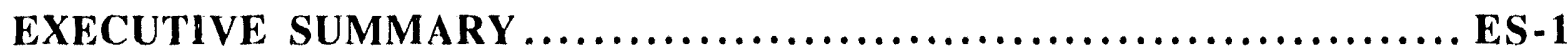

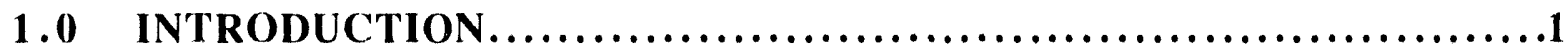

2.0 SUMMARY OF THE DOE ENVIRONMENTAL TECHNICAL

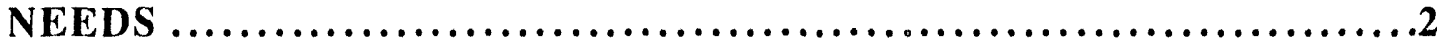

2.1 Chemical Contaminants on DOE Lands and Selection of Contaminant

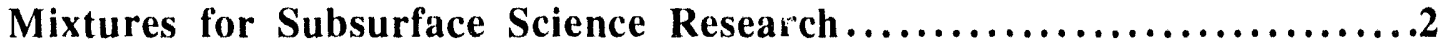

2.2 Needs Assessment Report..............................................4

2.2.1 Environmental Problems .................................4

2.2.2 Remediation Technology Deficiencies...........................5

2.2.3 Characterization Technology Needs.............................

2.2.4 Savannah River Needs......................................8

2.3 Technology Needs Crosswalk .......................................

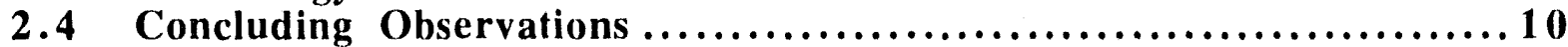

3.0 SUMMARY OF THE EPA AND DOD ENVIRONMENTAL

TECHNOLOGY NEEDS........................................ 11

3.1 Summary of EPA Environmental Technology Needs $\ldots \ldots \ldots \ldots \ldots \ldots \ldots 11$

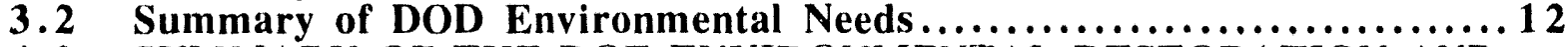

4.0 SUMMARY OF THE DOE ENVIRONMENTAL RESTORATION AND

WASTE MANAGEMENT FIVE-YEAR PLAN.................... 14

4.1 DOE Mission .................................................. 14

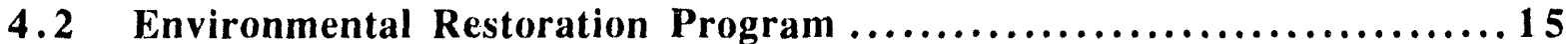

4.3 Technology Development ...................................... 15

4.4 Summary of the SRS Five-Year Plan--Strategic Outlook............ 18

5.0 CONCLUSION.................................................. 19

5.1 National Environmental Needs ................................. 19

5.2 Departmentof of Energy Environmental Needs.................... 19 


\section{LIST OF TABLES}

1 ENVIRONMENTAL PROBLEMS AT OPERABLE UNITS.............6

2 ENVIRONMENTAL PROBlems, PROBlem UNITS, AND TTPS.... 10

3 ENVIRONMENTAL PROBLEMS AND THE SITE PROGRAM......... 11

4 ENVIRONMENTAL REMEDIATION TECHNOLOGIES .............13

5 ENVIRONMENTAL NEEDS FOR DOE, DOD, AND EPA $\ldots \ldots \ldots \ldots \ldots 20$ 
D\&D Decontamination and Decommissioning

DNAPL Dense Non-Aqueous Phase Liquid

DOD Department of Defense

DOE Department of Energy

DQO Data Quality Objectives

EM-40 Office of Environmental Restoration

EM-50 Office of Technology Development

EPA Environmental Protection Agency

ER Environmental Restoration

ESP Extended Sludge Processing

FY Federal Year

IDP Integrated Demonstration Program

$\mathrm{mCi} / \mathrm{L} \quad$ Millicurie Per Liter

MWMF Mixed Waste Management Facility

NAPL Non-Aqueous Phase Liquid

OTD Office of Technology Development

PCBs Polychlorinated Biphenyls

ppb Parts Per Billion

ppt Part Per Thousand

RCRA Resource and Conservation Recovery Act

R\&D Research and Development

ROD Record of Decision

SITE Superfund Innovative Technology Evaluation

SRL Savannah River Laboratory

SRS Savannah River Site

SRTC Savannah River Technology Center

TD Technology Development

TRU Transuranic

TTP Technology Task Plan

$\mu \mathrm{C}, \mathrm{L} / \mathrm{L} \quad$ Microcurie Per Liter

VOC Volatile Organic Compound

WM Waste Management 


\section{EXECUTIVE SUMMARY}

The Office of Technology Development of the U.S. Department of Energy (DOE) has directed the Savannah River Technology Center to implement an Integrated Demonstration Program at Savannah River Site to assess new environmental remediation systems and technologies and transfer them to other DOE sites and private industry for use in full-scale remediation efforts. The first phase of the Integrated Demonstration Program is coming to a successful conclusion and the Savannah River Technology Center has asked a panel of environmental experts to prioritize national, DOE, and Savannah River Site environmental problems and make programmatic recommendations for future technology research and demonstrations.

This document is a summary of national and DOE environmental problems that are common to Savannah River Site and was created as a decision making tool for the expert panel. There are many diverse environmental problems, therefore the summary has been limited to environmental problems that are significant to the Savannah River Site. National environmental problems were summarized from U.S. Environmental Protection Agency and U.S. Department of Defense documents. The DOE and Savannah River Site environmental problems were summarized from three documents: the Chemical Contaminants on DOE Lands and Selection of Contaminant Mixture for Subsurface Science Research (DOE/ER-0547T); the Technology Needs Assessment Final Report (DOE/ID/12584-92); and the Technology Needs Assessment II - Crosswalk (DOE/ID/12584-117).

National environmental problems identified in the summary are soil and water contaminated with organic compounds. Specifically, groundwater contaminated with dense non-aqueous phase liquid hydrocarbons was found to be a significant national environmental problem.

The DOE environmental problems identified in the summary are soil and water contaminated with fuel and chlorinated hydrocarbon compounds, metal compounds, and radioactive elements.

Savannah River Site environmental problems identified in the summary are soil and groundwater contaminated with chlorinated hydrocarbons, metal compounds, tritiated water, and other radioactive elements.

Technology deficiencies that were identified in the summary were deficiencies in in situ remediation technologies, in situ characterization technologies, and in situ isolation and containment technologies. 


\subsection{INTRODUCTION}

The U. S. Department of Energy (DOE) operates the Savannah River Site (SRS) to produce nuclear weapons for the national defense program. As a result of past waste handling activities and current environmental concerns by both the public and regulatory agencies, remediation of contaminants within the environment is an important issue with DOE. The Office of Technology Development (OTD) of DOE has funded the Savannah River Technology Center (SRTC) to implement the Integrated Demonstration Program (IDP) at the SRS to assess new environmental remediation systems and technologies and transfer them to DOE sites and private industry for use in full-scale remediation efforts. The SRTC has successfully concluded the initial IDP. The IDP has now been funded to assess additional environmental problems that are of national concern, common to SRS, and for which there are deficiencies in the current remediation and characterization technologies.

A panel of environmental experts will be convened to evaluate environmental restoration needs at SRS, other DOE sites, U.S. Department of Defense (DOD) sites, and U.S. Environmental Protection Agency (EPA) sites. The panel will evaluate national and SRS environmental problems and make programmatic, prioritized recommendations for future IDP technology research and demonstrations. The SRTC has created this document as a decision making tool for the panel.

This document provides the panel with a summary of national environmental needs, DOE environmental needs, and SRS environmental needs. The SRTC has reviewed and summarized documents from the Environmental Protection Agency and the DOD to determine national environmental needs. To compile DOE and SRS environmental needs the SRTC has summarized four DOE documents including: the Chemical Contaminants on DOE Lands and Selection of Contaminant Mixture for Subsurface Science Research (DOE/ER-0547T); the Technology Needs Assessment Final Report (DOE/ID/12584-92); and the Technology Needs Assessment II Crosswalk (DOE/ID/12584-117). This document also provides the panel with a summary of the Environmental Restoration and Waste Management Five-Year Plan (DOE/S-00097P). The latter summary will be used to ensure that future IDP activities are compatible with DOE environmental goals. 


\subsection{SUMMARY OF THE DOE ENVIRONMENTAL TECHNICAL NEEDS}

The DOE has conducted three studies to identify environmental technology needs: the Chemical Contaminants on DOE Lands and Selection of Contaminant Mixture for Subsurface Science Research (DOE/ER-0547T), the Technology Needs Assessment Final Report (DOE/ID/12584-92), and the Technology Needs Assessment II - Crosswalk Report (DOE/ID/12584-117). The first report will be referred to in this document as the Chemical Contaminant Report, the second will be referred to as the Needs Assessment Report, and the third will be referred to as the Crosswalk Report.

\subsection{Chemical Contaminants on DOE Lands and Selection of Contaminant Mixtures for Subsurface Science Research}

The DOE initiated the Subsurface Science Program to conduct basic research on hydrologic, microbiologic, and geochemical mechanisms that operate in subsurface environments and that control contaminant migration persistence, and ease of remediation. The Chemical Contaminants on DOE Lands and Selection of Contaminant Mixture for Subsurface Science Research (DOE/ER0547T) was written as a source document for the Subsurface Science Program. The document provides a review of the types of contaminants that have been released to the ground at $18 \mathrm{DOE}$ facilities and that have been identified to be present in soils, sediments, and ground water at the sites.

Published information has documented that the chemical composition of contaminants at DOE facilities is complex. Reports of codisposal of inorganic and radioactive contaminants with the following contaminants are common: (1) chlorinated solvents; (2) fuel hydrocarbons; (3) plasticizers; (4) polychlorinated biphenyls (PCBs); (5) alkyl phosphates; (6) conventional explosives; (7) complexing agents; (8) organic acids; (9) pesticides; and others. These compound classes have been reported in groundwaters at concentrations ranging from parts per billion (ppb) to parts per thousand (ppt) levels. In the case of radionuclides, radioactivity in groundwaters has been reported that ranges up to micocuries per liter $(\mu \mathrm{Ci} / \mathrm{L})$ for non-tritium radionuclides to millicuries per liter $(\mathrm{mCi} / \mathrm{L})$ for tritium. The Chemical Containment Report tabulates frequency of occurrence of each of the compounds or elements for selected sites from the DOE complex.

The compound classes most commonly reported in soils and sediments were fuel hydrocarbons, followed by chlorinated hydrocarbons, metals, and radionuclides. Less commonly reported compound classes included anions, (e.g., nitrate, fluoride, and cyanide) ketone, and PCBs. 
Organic acids, plasticizers, explosives, alkyl phosphates, complexing agents, and pesticides were reported at only two to five facilities. The most frequently reported binary compound-class mixture in soils/sediments was metals and radionuclides. The ternary combination of metals, chlorinated hydrocarbons, and radionuclides was found to be ubiquitous in soils/sediments at the DOE complex

The compound classes most commonly found contaminating groundwater were chlorinated hydrocarbons, metals, followed by radionuclides, anions, fuel hydrocarbons, and ketones. Reported with less frequency were plasticizers, explosives, and organic acids. Pesticides, PCBs, and complexing agents each occurred at only one facility. The most frequently reported binary compound-class mixture in groundwater was metals and chlorinated hydrocarbons: this mixture was present at 12 of the 18 facilities studied. Other important binary mixtures were metals and radionuclides, metals and anions, anions and radionuclides, radionuclides and chlorinated hydrocarbons, and anions and chlorinated hydrocarbons. These mixtures were reported at greater than 50 percent of the facilities. Ternary compound-class mixtures including metals, radionuclides, chlorinated hydrocarbons, and anions in various combinations, occurred at more than 50 percent of the facilities.

Examination of the tables for the SRS contaminants suggests that the survey under estimates the frequency of occurrence of some contaminants, and over estimates others. The survey tabulated contaminants from only nine out of 200 sites at SRS. The following nine sites were included in the study: the M-Area Settling Basin, CMP Pit 1, CMP Pit 2, TNX Seepage Basins, Coal Pile Containment Basins, Metallurgical Laboratory Basin, Savannah River Laboratory (SRL) Seepage Basins, Radioactive Waste Burial Grounds, and the 200F/200H Seepage Basin. The latter four facilities were/are operated as the principal radioactive waste disposal facilities at SRS; therefore, the survey over estimates the frequency of radionuclide contamination at SRS. Another example of over estimating the frequency of radionuclide contamination is the Coal Pile Run-off Basin. Because the tabulation of contaminants has no concentration threshold, the naturally occurring "radioactivity" associated with the coal pile, the coal pile leachates, and other minor facilities is weighted as heavily as a radioactive waste burial ground.

Examination of the remaining sites and interviews with SRS staff indicate that most SRS hazardous waste sites contain rubble, chlorinated solvents and/or fuel hydrocarbons with substantially lower numbers of facilities receiving radioactive disposals. As an example, radionuclides, metals, and organic compounds were all identified (equal weight) as groundwater contaminants below the M-Area Settling Basin. Note, however, that in 1991 the maximum 
exceedances (maximum concentration / standards) of drinking water standards were : 150,000x for organic compounds (mostly trichloroethylene); 60x for inorganic compounds (mostly nitrates); $4 \mathrm{x}$ for non-tritium radionuclides (gross alpha); and $3 x$ for tritium. Thus, because of the relative disposal quantities, the relative contaminant mobilities, and the identification of both dense nonaqueous phase liquid hydrocarbons and aqueous phase liquid hydrocarbons in the groundwater, the non-fuel solvents continue to receive the highest priority from the SRS Environmental Restoration Program and the regulators.

The general conclusions of the Chemical Contaminant Report may be misleading if the SRS contaminant tabulation is representative of the results from the DOE complex as a whole. The relative importance of radionuclide contamination, as stated in the Chemical Contaminant Report, is over estimated and the relative importance of organic contamination is under estimated.

\subsection{Needs Assessment Report}

The Needs Assessment Report is a compilation of 300 environmental needs (problems), 100 technologies to address those needs, 640 environmental restoration technology deficiencies, 250 characterization needs, and 225 other factors that were known to influence environmental restoration prior to its publication. The DOE has performed many environmental remediation investigations since the information in the report was gathered and, therefore, some of the conclusions, such as frequency of contaminant occurrence, found in the report are now obsolete. This summary will present information from the Needs Assessment, but will refrain from presenting conclusions that are believed to be out of date.

The report placed the aforementioned information into three main categories: problems, technology deficiencies, and characterization needs. These three main categories are discussed in the following sections.

\subsubsection{Environmental Problems}

Environmental problems were defined as problem unis that were: (1) a single operable unit as identified in a regulatory agreement, (2) all problems existing in a given geographical area of a site, or (3) all problems at a site of a similar nature, such as underground petroleum storage tanks. The environmental problems were put into groups. The groups were primarily based on the location of the contaminant (operable unit), secondarily on contaminated media, and thirdly on contaminant type. The environmental problem groups were examined using the following criteria: 
- Is the contaminant one that DOE is uniquely qualified to address?

- Does the deficiency stand in the way of solving a significant contamination problem in terms of source, volume, or toxicity?

- Does the contamination represent a significant current or near-term potential risk to workers, the public, and/or the environment?

- Is the Environmental Restoration (ER) requirement widely identified across the DOE complex?

- Have other, similar ER requirements been successfully addressed with the existing technologies?

The environmental problem groups identified were areas of organic contamination that constitute a current or potential source of groundwater contamination, and media contaminated with metal and radioactive compounds and elements. Environmental remediation technologies depend less on operable units and more on the contaminant and the contaminated inedia, therefore, this summary will define the problems not by operable units or sites but as common remediation problems. For example, in this summary soil contaminated with solvents beneath a pipeline will be grouped with soil contaminated with solvents beneath an underground storage tank.

The environmental problems are listed in Table 1 with the number of problem units that were identified across the DOE complex at the time the Needs Assessment Report was written.

\subsubsection{Remediation Technology Deficiencies}

A remediation technology deficiency is defined as a deficiency that inhibits the implementation of a technology, a group of technologies, or a remedial alternative being considered by site personnel for remediation of an identified contamination problem. The deficiencies were ranked (high, medium, and low priorities) according to the following three criteria:

1. Does the deficiency significantly hinder the stection and implementation of a given technology?

2. Does the deficiency apply to multiple ER needs by virtue of contaminants or media addressed?

3. Does solving the deficiency aid in the resolution of other deficiencies associated with the same or other technologies? 
Table 1. Environmental Problems at Operable Units

\begin{tabular}{|l|c|}
\hline Environmental Problems & $\begin{array}{c}\text { Number of } \\
\text { Operable Units } \\
\text { with Problem }\end{array}$ \\
\hline Soils/Sludges contaminated with: \\
\hline Organic Compounds & 27 \\
\hline $\begin{array}{l}\text { Metal/Radioactive Compounds or Elements } \\
\text { Groundwater and Surface Water contaminated } \\
\text { with: }\end{array}$ & 87 \\
\hline Oiganis Compounds & 13 \\
\hline NAPLs & 19 \\
\hline Aqueous Phase Liquids & \\
\hline $\begin{array}{l}\text { Metal/Non-Tritium Radioactive Compounds or } \\
\text { Elements }\end{array}$ & 25 \\
\hline \begin{tabular}{l} 
Tritium \\
\hline
\end{tabular}
\end{tabular}

The following remediation technology groups (with associated needs) were identified as needing to be improved and/or developed to resolve environmental technology deficiencies.

Removal and Recovery - remote retrieval, pumping, mechanical removal, french drains, under tanks, ponds, and buildings

- Better and more acceptable methods are required for evaluating the need for remediation and setting remediation goals.

- Better methods are needed for recovery of groundwater.

Ex Situ Treatment - ion exchange, vitrification, bioremediation, and air stripping

- Better methods are required to minimize secondary waste during ex situ treatment of all contaminated media types and to stabilize and evaluate secondary waste forms,

- Currently used methods for ex situ treatment must be developed to be more efficient or effective.

- Methods for real-time monitoring of ex situ treatment processes are needed to save time and reduce uncertainty associated with treatment.

In Situ Treatment - vitrification, solidification, air stripping, under tanks, ponds, buildings; and experimental treatment

- Further development of largely unproven in situ treatment technologies is necessary for these methods to become more acceptable. 
- In situ treatment methods to reduce contaminant concentrations to levels lower than achievable with current technology are needed.

- Development of in situ treatment techniques for use at greater depths and areas complicated by the presence of surface or subsurface structures are needed so these technologies can have wider application.

In Situ Isolation/Containment - slurry walls, grout curtains, cryogenic barriers, hydraulic isolation, under tanks, ponds, and buildings

- Performance criteria must be established and methods developed for verifying and monitoring that criteria are met for both in situ treatment and isolation of all contaminant types.

- Uncertainty regarding the long-term effectiveness of in situ isolation methods must be removed if these technologies are to become widely acceptable.

\subsubsection{Characterization Technology Needs}

The Needs Assessment Report identified 250 individual characterization needs that were placed in 29 discrete categories. A characterization need is defined as any activity or system that supports the identification of physical and chemical properties of a site requiring environmental restoration. The categories are listed below along with the number of times (in parenthesis) the need was mentioned by ER personnel.

- Analytical (68) - real-time field analysis of all contaminants, mobile labs, reliable and fast fixed-base labs, remote analysis systems

- Non-intrusive (41) - dense non-aqueous phase liquids (DNAPLs), characterize wastes, geology, hydrology, surface geophysics

- Data Quality Objectives (DQO) (38) - develop reasonable, uniformed approach to DQO selection

- Sampling (31) - deep groundwater volatile organic compound (VOC) samples, sampling under structures, continuous sampling and monitoring

- Drilling (18) - directional drilling, dry drilling, control contaminants while drilling

- Physical Characterization (18) - water table, contaminant plumes, hydrogeologic properties

- Modeling (11) - improved flow and transport modeling, fracture flow, non-aqueous phase liquid (NAPL), geochemical, colloid transport

- Geophysical Bore Hole Logging (3) - improve downhole geophysical techniques. 


\subsubsection{Savannah River Site Needs}

The high priority environmental restoration issues for the SRS were identified as follows:

- $\mathrm{A} / \mathrm{M}$ Area groundwater and vadose zone - The metal compounds released in the area have been stabilized in the soil prior to Resource Conservation and Recovery Act (RCRA) closure. The main contaminants in the area are aqueous phase and no aqueous phase liquid hydrocarbons and special chlorinated hydrocarbons.

- Low-level radioactive waste disposal facility and associated groundwater contamination - The main contaminants are organic compounds, metal compounds, and tritium in groundwater and metal and radionuclide compounds and elements in soil.

- High-level waste tank farm - The main contaminants are tritium and other radionuclides.

- R-Area seepage basin soils - The main contaminants are radionuclides in the soil.

- Old F-Area basin - The main contaminants are metal and radionuclide compounds and elements in the soils.

- New F- and H-Area seepage basin - The main contaminants are tritium, nitrates, other radionuclides, and metals in groundwater. The metal and radionuclide compounds and elements in the soil have been stabilized prior to RCRA closure.

\subsection{Technology Needs Crosswalk Report}

The Crosswalk Report is a mechanism for matching technologies with environmental restoration needs and for establishing a communication system between the Office of Environmental Restoration (EM-40) and Office of Technology Development (EM-50). The Crosswalk Report is designed to enable each reader to focus on important information. For example, a technology developer can identify potential end users of a given technology, determine when that technology is needed, and find out what performance criteria must be met. The user (customer) of technologies can identify who is developing a new technology that matches the required need, when the technology will be available, and what the performance capabilities of the technology are.

The Crosswalk mechanism consists of a database and a set of worksheets. The database is structured similar to the worksheets and in essence is an electronic copy of the worksheets. The Crosswalk user may query the database by using a keyword search. The keyword search will compile a list of problem units and/or Technology Task Plans (TTPs) with the attributes of interest that are identified by worksheet identification numbers. The user can then use worksheet identification numbers to consult the worksheets for detailed results. 
The Crosswalk Report is only a snapshot in time of the EM-40 and the EM-50 programs. As information for the Crosswalk Report was being collected, it was noted that many changes had occurred in DOE's environmental restoration program since the initial data collection effort during the Technology Needs Assessment. For example, DNAPL petroleum hydroc'a bons were not seen as a major problem in the DOE complex until recently. The Crosswalk database will require regular updates to reflect the dynamic nature of environmental restoration and technology development activities. The TTPs included in the Crosswalk Report may provide only support functions or paper studies and are not actual technology development projects. The TTPs may also pertain to only small, though often important, components of a larger system and do not represent a complete restoration technology. Therefore, the numbers in the following table over represent the number of remedial systems that are being developed. Furthermore, the database keyword system was designed to present the maximum number of records during a keyword search. For example, a report produced by a search for a TTP using a keyword combination of SOIL and ORGANICS and IN SITU would including the following record:

- In Situ Containment \& Stabilization of Buried Waste

- Low-level waste, trichloroethylene, all physical settings, concrete, containment, disposal, encapsulation, ex situ, grouting, immobilization, in situ, metal objects, metals, mixed waste, organics, rad, sludges, soil, stabilization, transportation, treatment.

The same record would be recovered from the database with a search using the keyword combination METALS and EX SITU and TRANSPORTATION.

A Crosswalk Report summary is found in Table 2 and the result of a query of the database. The purpose of the search was to provide a gross tally of environmental problems and TTPs that address those problems. Environmental problems were entered as keywords, and tallies of problem units and TTPs associated with the environmental problem were recorded. As shown above, a problem unit or TTP may be listed in several different categories and therefore the following table lists environmental problems, their ranking, the gross number of associated problem units in DOE, and the gross number of associated TTPs. 
Table 2. Environmental Problems, Problem Units, and TTPs

\begin{tabular}{|l|c|c|}
\hline Environmental Problems & $\begin{array}{c}\text { Problems } \\
\text { Units }\end{array}$ & TTPs \\
\hline Soils/Sludges contaminated with: & 103 & 70 \\
\hline Organic Compounds & 125 & 81 \\
\hline Metals and Radioactive Compounds & & \\
\hline $\begin{array}{l}\text { Groundwater and Surface Water contaminated } \\
\text { with: }\end{array}$ & 148 & 117 \\
\hline Organic Compounds & 6 & 15 \\
\hline NAPL & N/A & N/A \\
\hline APL & 79 & 22 \\
\hline Metals and Radioactive Compounds & 31 & 0 \\
\hline Tritium
\end{tabular}

\subsection{Concluding Observations}

1. Based on the review of the DOE documents, the most pressing environmental restoration problems requiring research are:

- Soil contamination, particularly fuel hydrocarbons, chlorinated hydrocarbons, and radionuclides

- Groundwater contamination, particularly chlorinated hydrocarbons, metals, and radionuclides.

2. The most appropriate technologies for environmental restoration research are those that enhance removal and ex situ treatment options.

3. The establishment of DQOs, which is the driving force behind site characterization, must receive increased emphasis by DOE.

4. Cleanup goals, risk assessment, future land-use scenarios, and acceptable levels of uncertainty drive remediation alternatives. Development of uniform strategies to address these issues should be an important research effort.

5. A critical area for DOE research is development of effective plans and strategies to foster public and regulatory acceptance of environmental restoration activities.

6. Enhanced technology transfer is needed among DOE's field and site offices, DOE headquarters, other government agencies, and private industries. 


\subsection{SUMMARY OF EPA AND DOD ENVIRONMENTAL TECHNOLOGY NEEDS}

The following is a summary of the environmental technology needs of the DOD) and the EPA.

\subsection{Summary of EPA Environmental Technology Needs}

The summary of EPA environmental technology needs (Table 3) was created by searching the Superfund Innovative Technology Evaluation (SITE) Program: Technology Programs, Fifth Edition, for technologies that deal with the environmental problems listed in Section 1.1. The assumption was made that the EPA has awarded SITE projects based on EPA environmental needs. Therefore, the more SITE projects that deal with an environmental technology need, the higher the priority that need has in the EPA.

Table 3. Environmental Problems and the SITE Program

\begin{tabular}{|l|c|}
\hline Environmental Problems & $\begin{array}{c}\text { Number of SITE } \\
\text { Programs }\end{array}$ \\
\hline Soils/Sludges contaminated with: \\
\hline Organic Compounds & 76 \\
\hline Metal and Radioactive Compounds or Elements & 16 \\
\hline $\begin{array}{l}\text { Groundwater and Surface Water contaminated } \\
\text { with: }\end{array}$ \\
\hline Organic Compounds \\
\hline Metal and Radioactive Compounds or Elements & 31 \\
\hline
\end{tabular}

The above table indicates that the EPA emphasizes research into organic contaminated media. The EPA has further concluded that contamination resulting from release of DNAPLs to the subsurface is far more prevalent than previously believed and can control the ultimate success or failure of remediation at a hazardous waste site (Estimating Potential for Occurrence of DNAPL at Superfund Sites, January, 1992, 9355.4-07FS). Investigating for DNAPLs at a hazardous waste site is expensive and EPA has identified a need for research in the area of site characterization for DNAPLs along with recovery and treatment of DNAPLs. 


\subsection{Summary of DOD Environmental Needs}

In June 1992 the DOD published the Tri-Service Project Reliance Environmental Quality Area Summary, FY 93-98. The report represents the first six-year Environmental Quality Science and Technology plan prepared under the concept of interservice "Reliance" on science and technology produced by the other services. A tri-service environmental quality panel was created. The panel is divided into seven technology areas: Installation Restoration, Noise Abatement, Pollution Prevention, Base Support, Atmospheric Compliance, Global Marine Compliance, and Terrestrial and Aquatic Assessment. This summary will deal exclusively with Installation Restoration.

The Installation Restoration area provides the Research and Development (R\&D) necessary to develop and demonstrate technologies to reduce the projected high cost of cleaning up DOD installations designated as threats to human health and the environment. The area consists of three sub-areas: site investigation/characterization; explosives, fuels and solvents site contamination; and, other organic compounds and metals contaminant treatment. This sumınary will consider all elements of the above sub-areas except for the explosives contaminant treatment element.

Under the tri-service Reliance the Army is the lead service in the Site Investigation/Characterization area. The Army leads the tri-service research for developing the cone penetrometer with advanced sensors to investigate and characterize waste sites. The Air Force and Navy will continue to rely on the Army to provide site characterization technologies and analytical methods for the contaminant characterization. The Air Force will support the Army in developing site characterization technologies unique to fuels and solvents.

The tri-service Reliance provided a funding strategy for the R\&D of technologies and demonstrations of emerging technologies. Table 4 is a summary of the number of projects funded by DOD. The assumption is made that the number of funded projects for a particular technology reflects the importance that DOD places on the environmental problem and the technology remedies. The DOD did nut include remediation problems or technologies for mixed metal and organic waste or any radioactive waste. Therefore, those categories have been eliminated from the tables. 
Table 4. Environmental Remediation Technologies

\begin{tabular}{|l|c|c|}
\hline Environmental Problems & $\begin{array}{c}\text { Number of } \\
R \& D \text { Projects }\end{array}$ & $\begin{array}{c}\text { Number of } \\
\text { Demonstration } \\
\text { Projects }\end{array}$ \\
\hline Soils contaminated with: & \multicolumn{2}{|c|}{} \\
\hline Metal waste & 5 & 4 \\
\hline Organic waste & 10 & 13 \\
\hline Explosive waste & 10 & 6 \\
\hline Groundwater contaminated with: & 3 & \\
\hline Metal waste & 3 & 22 \\
\hline Organic waste & 1 & 1 \\
\hline Explosive waste & & \\
\hline
\end{tabular}

The above table indicates that media contaminated with organic compounds and/or explosives are a high priority environmental problem in the DOD. 


\subsection{SUMMARY OF THE DOE ENVIRONMENTAL RESTORATION AND WASTE MANAGEMENT FIVE-YEAR PLAN}

The DOE Environmental Restoration and Waste Management Five-Year Plan (Five-Year Plan) is a document that charts the course of DOE Environmental Management and Technology Development from FY 93 to FY 98. The document is necessarily broad in scope and is not able to provide the detail that the Needs Assessment Report or the Crosswalk Report provides. The following summary of the Five-Year Plan focuses on installation restoration and associated technology development.

\subsection{DOF. Mission}

In March 1989, Secretary of Energy James D. Watkins requested that all the near-term activities necessary to bring DOE into compliance with all applicable environmental requirements be detailed in one plan. The result was the Five-Year Plan. The information in the Five-Year Plan was based on Activity Data Sheets which reported financial and technical information at the installation level. The Five-Year Plan has developed into the primary planning tool for the DOE Office of Environmental Restoration and Waste Management. The FY 1994-1998 Five-Year Plan reports on the progress of DOE in carrying out its environmental mission, identifies what must be accomplished during the five-year period, describes strategies for achieving critical program objectives, and expresses DOE's commitment to a 30-year goal for cleanup of the 1989 inventory of inactive sites.

The goals for the environment, safety, and health activities in the Five-Year Plan are in order of importance:

- Prevent near-term adverse impacts to workers, the public, or the environment

- Meet the terms of legal mandates or procedural commitments required by DOE

- comply with external environmental regulations not addressed by the first two priorities

- Perform activities not required by regulations but which the DOE deems desirable. 


\subsection{Environmental Restoration Program}

The Environmental Restoration Program priorities are divided into three classes:

Class 1: Emergency activities, where funding and activities are initiated as soon as possible

Class 2: Time critical activities, where funding is guaranteed in the fiscal year in which the activity is implemented

Class 3: Other high-benefit and time-sensitive activities

\subsection{Technology Development}

The priorities of the Technology Development Program are to meet the needs of the Environmental Restoration and Waste Management Programs, other DOE offices, state and local regulators, policy-making bodies (i.e., the U.S. Congress), and the public. The needs of these groups fall into two broad categories:

Category 1: Technology development to meet Environmental Restoration and Waste Management requirements for clearly identified areas where current technology is insufficient

Category 2: Development of infrastructure (i.e., education and training related to technology resources), technology integration, emergency response and transportation.

Technology development challenges can be organized into six groups:

- Removal and Recovery - recovery of low-level, high-level, and transuranic (TRU) radioactive wastes need to be developed.

- In situ treatment and stabilization - current technologies are generally unproven, of questionable effectiveness, or in such an early stage of development that they require significant demonstration before they can be seriously considered.

- Ex situ treatment and stabilization - current waste treatment methods generate large volumes of secondary waste. DOE needs to minimize the secondary waste stream.

- Disposal - DOE needs to develop design criteria for waste disposal sites.

- In situ isolation - DOE needs to develop technologies that isolate contaminants from sources of drinking water. 
- Decontamination \& Decommission of nuclear facilities - current methods are very time- and labor-intensive and, consequently, costly. DOE needs better separation and partitioning methods to separate hazardous and radioactive components, to remove specific contaminants from mixtures, to separate diluted contaminants from concentrated mixtures, and to separate clean from contaminated materials. DOE also needs better methods to handle concentrated secondary waste streams.

Technology development must progress at an accelerated rate to be able to provide the Environmental Restoration Program with the tools to meet deadlines put forth in existing Record of Decisions (RODs). Federal year 1995 is a watershed year with respect to RODs and therefore, new technologies need to be available and operating by 1995. Environmental Restoration and Technology Development Programs must work together to develop appropriate characterization and treatment technologies. Technology transfer must be expedited to prevent delays. Delays from the regulatory approval process must be minimized.

Examples of technologies that must be enhanced are those that involve groundwater and soil technologies. Needed technologies would:

- Destroy contaminants in place;

- Remove and isolate contaninants for safekeeping

- Safely and permanently neutralize or immobilize the contaminants in place. In situ treatment methods are preferred for environmental restoration from both a technical and regulatory standpoint. In situ treatments protect workers and the public from contamination during clean up. High priority must be given to contaminants that exhibit mobility, high toxicity, and longterm persistence in the environment and that are present in large quantities, or at high concentrations, relative to levels of concern for human and ecological health.

The Technology Development program has made advances in the characterization and in situ treatment of soil and groundwater through new technologies for specific cleanup projects. Accomplishınents are summarized below ISRTC accomplishments placed in bold:

- Horizontal well technologies for site remediation

- Innovative drilling techniques

- Real-time monitoring of plutonium conitiminated soil

- Remote sensing methods using thermal imaging 
- Cone penetrometer use, electromagnetic mapping, and reflection seismology for in situ measurements to characterize soil and contaminants

- Full-scale demonstration project to clean up non-aqueous phase liquids, such as gasoline and other fuels, dynamic stripping utilizing thermal remediation, and underground imaging techniques.

Technology R\&D programs will pursue a multitude of techniques that improve and accelerate site characterization, increase the efficiency of remediating contaminated soil and groundwater, and facilitate regulatory acceptance of new technologies. Emphasis will be on the development of in situ treatment technologies. Planned program milestones for FY 1994-1998 are listed below with SRTC milestones placed in bold.

- Development of remote, non-invasive, non-destructive, and field deployable characterization systems to provide high-resolution, quantitative information for surface and subsurface characterization, containment detection, and monitoring of contaminant migration.

- Development of effective methods for treating and removing hazardous heavy metals from soils and groundwater, including mercury contamination at Oak Ridge, TN.

- Performance of further tests of in situ remediation technologies (i.e., bioremediation, electrokinetics, soll washing, air stripping of VOCs, and vitrification); including cold tests of selected thermal and electrical remediation technologies for mixed waste landfills

- Remediation activities for contaminated soils, including: development and demonstration of realtime sensors to enhance volume reduction goals of soil separation demonstration projects; soil treatability testing of soils from the Nevada Test Site; and industrial uranium- and plutoniumcontaminated soil separation demonstrations to serve as treatability testing for selected remedies under Federal Facility Compliance Agreements

- Demonstrations of off-gas destruction technologies to replace carbon adsorption techniques to eliminate wastes that are subject to land disposal restrictions 
- Pursue bioremediation technologies, in particular, complete the initial project to enhance indigenous microorganisms through methane injection, and the demonstration of characterization wells for bioremediation of VOCs in arid soils

\section{- Initiate thermal enhancement (in situ resistive heating and radio/frequency heating) methods for improving removal of solvents from clays}

These milestones will be accomplished using the most technically effective and cost-effective means possible, and will provide appropriate opportunities for public involvement.

\subsection{Summary of the SRS Five-Year Plan - Strategic Outlook}

The SRS mission, to be accomplished over a 30-yeur period, is to:

- Manage activities to achieve full compliance

- Treat, store, and dispose of the current inventory of waste

- Reduce new waste generation; clean up inactive waste sites

- Remediate contaminated groundwater; and D\&D surplus facilities

- Decontaminate and Decommission surplus facilities.

Seventeen major milestones are outlined in the FY 1994-1998 Five-Year Plan. These include closing seven sites (two are currently in progress), starting eight groundwater remediation programs (one currently in progress), and completing 63 waste site investigations (60 currently in progress).

Environmental Restoration activities include continued treatment of the A\&M-Area groundwater (over one billion gallons treated to date) and closure of the Metallurgical Laboratory Basin. Completed activities include closure of the F- and H-Area Basins, the M-Area Settling Basin, the Reactor Underground Storage Tank, and the Mixed Waste Management Facility (MWMF), and production of 39 Work Plans, seven Closure Plans and the Site Decontamination and Decommission Facility Assessment Document. 


\subsection{CONCLUSIONS}

\subsection{National Environ nental Needs}

The EPA and DOD have placed greater emphasis on research and demonstrations in technologies that remediate organic contaminated media than technologies that deal with metals or radionuclide contaminated media. The EPA has further concluded that many superfund sites have a greater amount of media contaminated with DNAPLs hydrocarbons than was previously thought. The DNAPLs create a secondary source of contamination that can ultimately control the success or failure of remediation at a hazardous waste site. There is a need for research and development of in situ and ex situ technologies that treat groundwaler and soil contaminated with DNAPLs.

\subsection{Department of Energy Environmental Needs}

The environmental needs of the DOE were identified in the Chemical Contaminants on DOE Lands and Selection of Contaminant Mixture for Subsurface Science Research (DOE/ER-0547T). The most prevalent DOE environmental problems are soil and groundwater contaminated with fuel and chlorinated hydrocarbons, followed by soil and groundwater contaminated with metal and radionuclide compounds and elements.

Environmental technology deficiencies in the DOE identified in this summary are deficiencies in in situ treatment and characterization technologies.

The SRS environmental problems are dominated by soil and groundwater contaminated by fuel and chlorinated hydrocarbons. Other environmental problems are associated with soil and groundwater contaminated with metal and radionuclide compounds and elements.

Table 5 presents the environmental needs put forth by the documents reviewed in this summary. 
Table 5. Environmental Needs for DOE, DOD, and EPA

\begin{tabular}{|l|c|c|c|c|c|c|}
\hline & $\begin{array}{c}\text { Number } \\
\text { of DOE } \\
\text { Problem } \\
\text { Units }\end{array}$ & $\begin{array}{c}\text { Crosswalk } \\
\text { DOEE } \\
\text { Problems } \\
\text { Units }\end{array}$ & $\begin{array}{l}\text { Crosswalk } \\
\text { DOE TTPs }\end{array}$ & $\begin{array}{c}\text { Number } \\
\text { of SITE } \\
\text { Programs }\end{array}$ & $\begin{array}{c}\text { Number } \\
\text { of DOD } \\
\text { R \& D D } \\
\text { Projects }\end{array}$ & $\begin{array}{c}\text { Number } \\
\text { of DOD } \\
\text { Demo- } \\
\text { Projects }\end{array}$ \\
\hline Soils/Sludges contaminated with: & & & & & \\
\hline Organic Compounds & 27 & 103 & 70 & 76 & 10 & 13 \\
\hline $\begin{array}{l}\text { Metal and/or Radioactive } \\
\text { Compounds or Elements }\end{array}$ & 87 & 125 & 81 & 16 & 5 & 4 \\
\hline Explosives & & & & & 10 & 6 \\
\hline Ground Water and Surface Water contaminated with: & & & \\
\hline Organic Compounds & & 148 & 117 & 31 & 3 & 22 \\
\hline NAPLs & 13 & 6 & 15 & & 3 & 0 \\
\hline $\begin{array}{l}\text { Metal and/or Non-Tritium } \\
\text { Radioactive Compounds } \\
\text { or Elements }\end{array}$ & 19 & 79 & 22 & 15 & & \\
\hline Tritium & 25 & 31 & 0 & & & \\
\hline Explosives & & & & & 1 & 1 \\
\hline
\end{tabular}



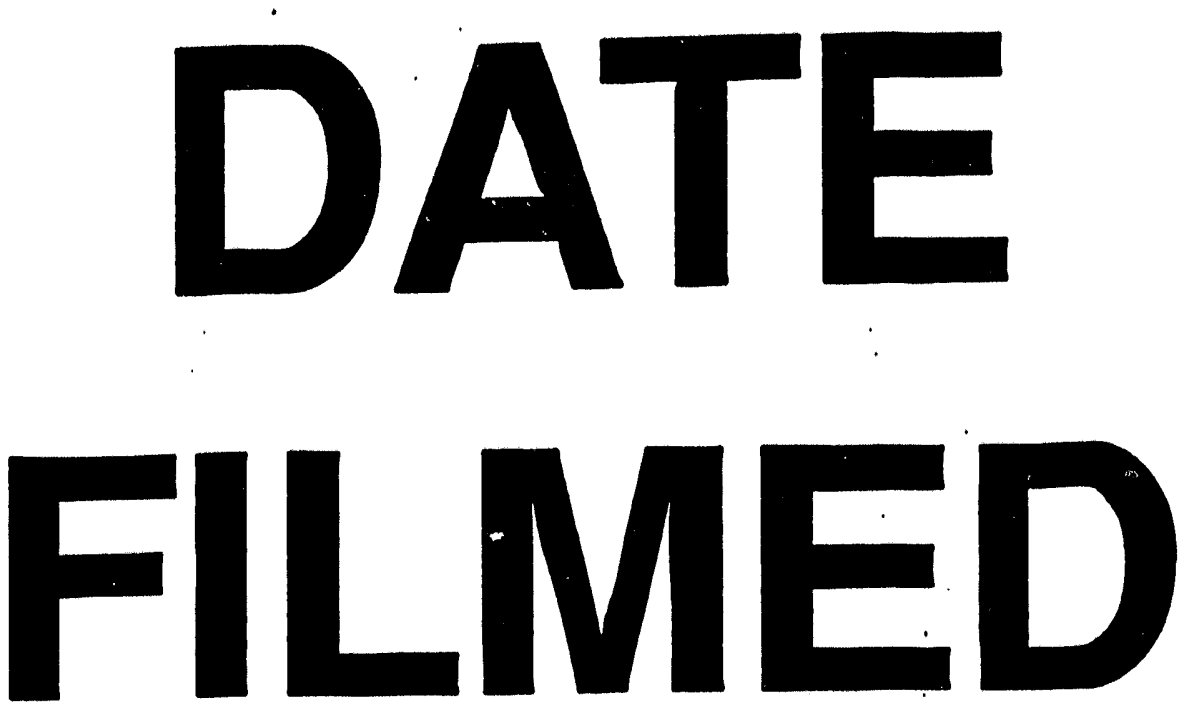

$11 / 17 / 93$
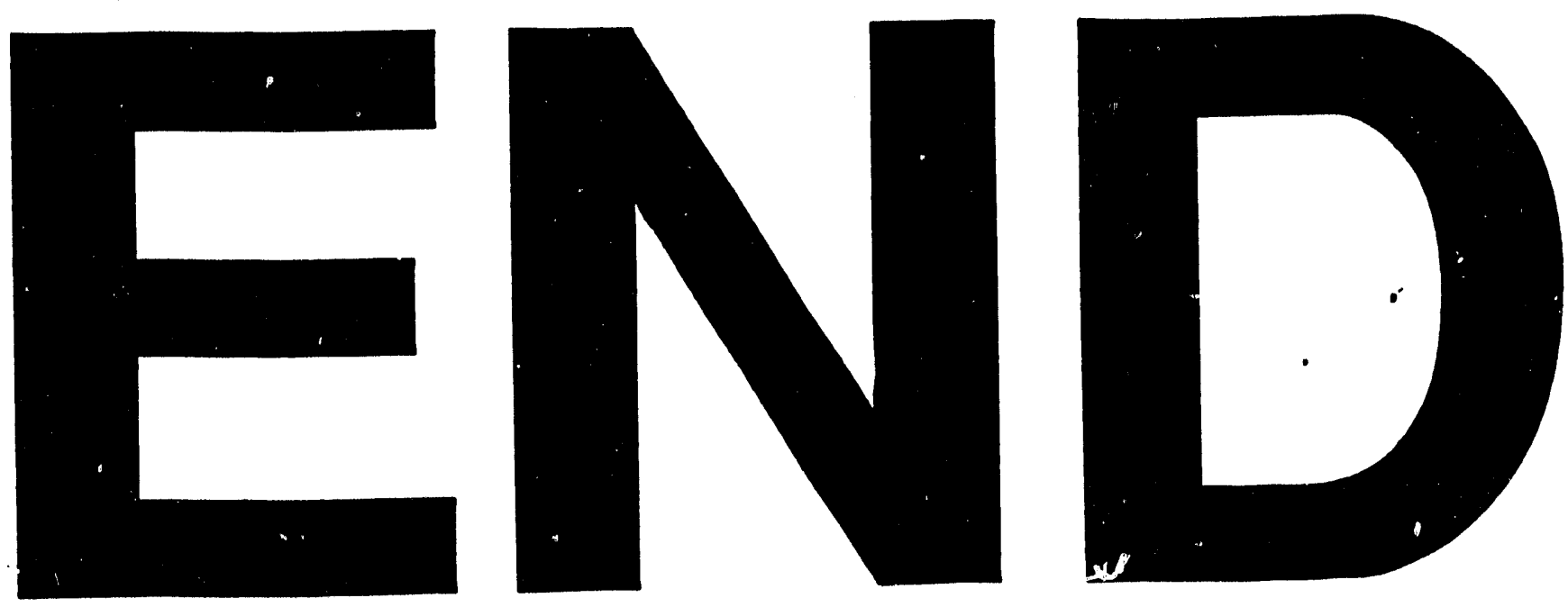

nسm
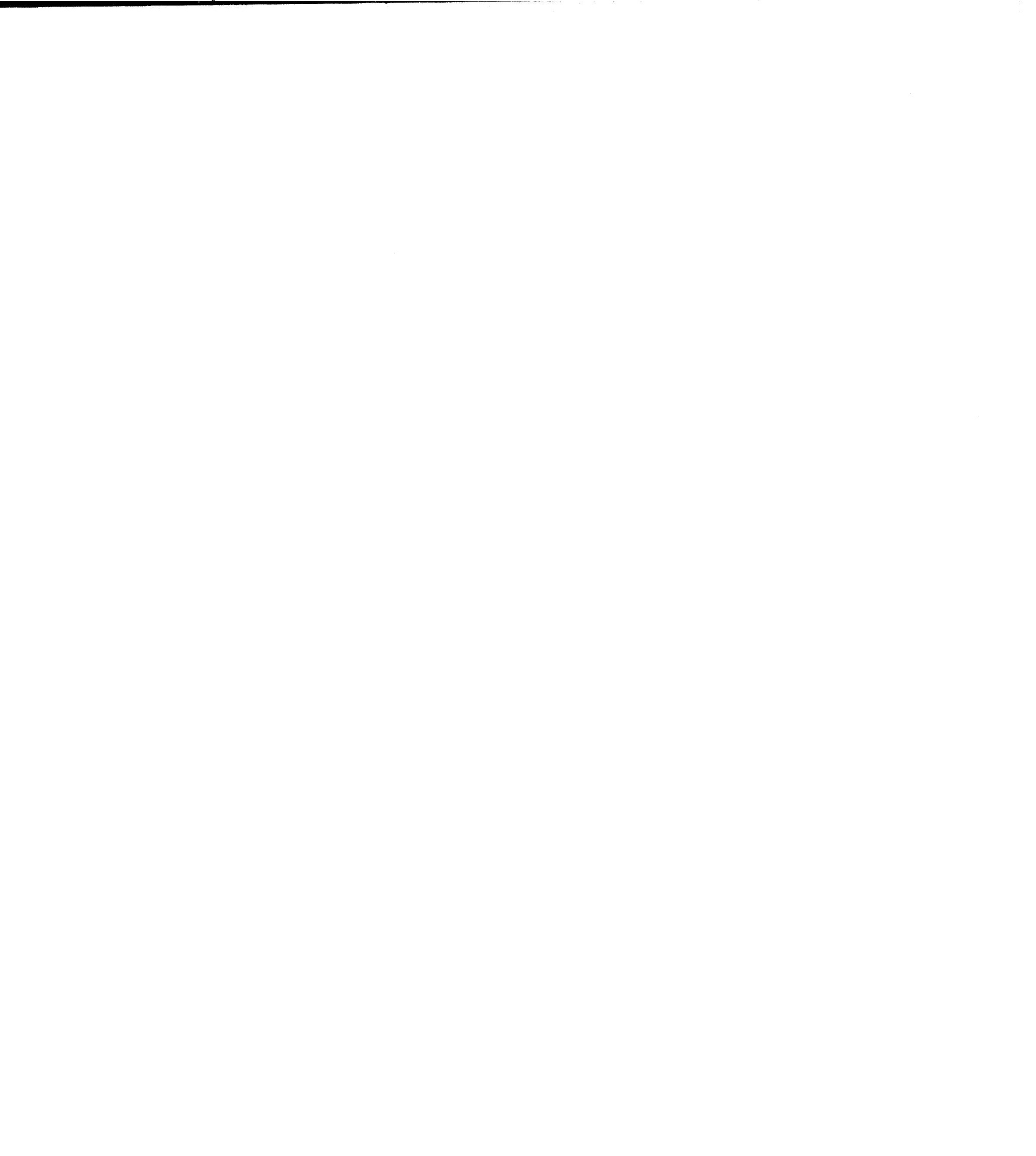